\title{
Information seeking behavior and associated factors among construction workers towards HIV/AIDS in Debre Berhan town, Northeast Ethiopia, 2019
}

MULUKEN TESSEMA ( $\square$ mklitmuluken@gmail.com )

Research article

Keywords: HIV, AIDS, EPI

Posted Date: March 24th, 2020

DOl: https://doi.org/10.21203/rs.3.rs-18742/v1

License: (c) (1) This work is licensed under a Creative Commons Attribution 4.0 International License. Read Full License 


\section{Abstract}

Background: Information seeking behavior is the purposive seeking for information as a consequence of a need to satisfy some goals. Information is crucial for preventing the spread of the virus as there is no cure or vaccination for HIV/AIDS. The aim of this study is to assess information seeking behavior and associated factors among construction workers towards HIV/AIDS in Debre Berhan town, Northwest Ethiopia.

Methods: Institution based cross-sectional study was conducted. A total of 705 construction workers were included in the study. Multistage sampling technique was used to select the study participants. A structured pretested interview questionnaire was used for data collection. The data were entered and cleaned in EPI info and exported in to SPSS version 16 statistical package for analysis. Binary logistic regression was used to identify associated factors. A p-value of 0.05 was taken as a cut off value for statistical significant association.

Results: Out of 705 workers, 200(28.4\%) were categorized as having inappropriate information seeking behavior towards HIV/AIDS. Comprehensive knowledge of HIV/AIDS [AOR=2.26, 95\% Cl: 1.47-3.50], workers who received HIV information from work place [AOR=1.52, 95\% Cl:1.00-2.29] and tested for HIV [AOR=1.81, 95\% Cl:1.19-2.73] were more likely to have appropriate information seeking behavior towards HIV/AIDS whereas female construction workers [AOR $=0.39,95 \% \mathrm{Cl}: 0.27-0.56]$ were less likely to have appropriate information seeking behavior towards HIV/AIDS.

Conclusion: Appropriate information seeking behavior towards HIV/AIDS among construction workers was not satisfactory. Comprehensive knowledge of HIV, information received from work place, being tested for HIV and workers sex (gender) affects information seeking behavior towards HIV/AIDS. Work place HIV prevention and control strategy need to be implemented to increase appropriate information seeking behavior towards HIV/AIDS.

\section{Background}

Information seeking behavior is the purposive seeking for information as a consequence of a need to satisfy some goals. In the course of seeking, the individual may interact with manual information systems: formal (hard and soft copies) and informal (human resources) (1-3.

As there is no vaccine or cure for HIV /AIDS, information is crucial for preventing the spread of the virus. Through widespread information about HIV/AIDS, the people of sub-Saharan Africa can gain the knowledge needed to change their behavioral response to the AIDS epidemic(4).

Thirty four million people were living with HIV at the end of 2011 globally. Sub-Saharan Africa remains most severely affected, with nearly 23.5 million people living with HIV. An estimated 1.2 million Ethiopians were living with HIV/AIDS in 2010. The prevalence of HIV among construction workers was approximately $11.6 \%$ which is significantly higher than the national urban adult population prevalence 
(4.2\%) and they are among most at risk populations and have less access to information to prevent HIV/AIDS(5-7).

Ethiopia represents a stable, low-level, generalized epidemic with marked regional variations driven by MARPs(8). Prevalence in 10 HIV hot spots in the Amhara Regional State was much higher (between $11.6 \%$ and $37 \%$ ) among sex workers, day laborers, truck drivers, mobile merchants, and students. This prevalence was also much higher than the national urban population prevalence (9). Construction workers are vulnerable and at risk of HIV infection(10).

Ethiopia is undergoing nationwide economic development efforts that include large construction activities throughout the country. HIV/AIDS has a triple impact on the construction sector, that is, impact on workers, on construction sectors and on the economy as a whole. So this study will try to assess information seeking behavior of workers, which is a vital component to prevent and control HIV/AIDS among most at risk populations(11).

Study objective

The objective of this study was to assess information seeking behavior and associated factors among construction workers towards HIV/AIDS in Debre Berhan town construction site,2019.

\section{Methods}

Study area and period: - The study was conducted in Debre Berhan town which is found in Amhara regional. According to the 2007 population and housing census report, the total population of Debre Berhan town is estimated to be 150,987 . Debre Berhan town has a total of 49 level-I and level-II construction sites and 6835 construction workers actively engaged during the preliminary survey on March 5, 2019.

Study design and period: - An institution based cross-sectional quantitative study was conducted from April 15 - 24, 2019.

Source population: - The source population includes all construction workers in Debre Berhan town level-I and level-II construction sites.

Study population: - The study population was construction workers in the selected construction sites in Debre Berhan town. Workers seriously ill, unable to respond to the questions and less than 3 months of working experience in the construction sector during the data collection time were excluded from the study.

Sample size and sampling procedures:- The sample size for this study was calculated -using the assumption that the proportion of information seeking behavior towards HIV/AIDS is $50 \%, 95 \%$ confidence interval, $5 \%$ marginal error, design effect of 2 and $10 \%$ non-response rate. A total of 705 construction workers were included for the study. 
Sampling technique: Multistage sampling technique was employed. All the 49 construction sites were stratified in to two levels: 10 were level-I and 39 were level-II. From level-I construction site, two were selected and from level-II construction site eight were selected using computer generated random number. The numbers of workers to be included in each construction site were determined in proportion with the total number of workers found in each construction site.

Data collection procedures: - A structured questionnaire was adapted from ILO work place HIV education project, Goswami and Melkote (1997) and UNAIDS(27). It was first prepared in English, translated to Amharic and then translated back to English to check for consistency.

The questionnaire was pre-tested in five construction sites on $5 \%$ of study participants.

Data were collected by interview technique using a structured questionnaire by ten third year health science students. Two masters of public health students and the principal investigator did the supervision work.

Of the 10 questions adopted from Goswami and Melkote (1997), workers who had information seeking behavior score of equal to or greater than the median score of the study population were categorized as having appropriate information seeking behavior towards HIV/AIDS.

Data quality control: - In order to ensure the quality of the data structured and pre-tested questionnaires were used to collect data. Training was given by the principal investigator on the objective, relevance of the study, confidentiality of information, respondent's right, informed consent and techniques of interview with respect to the study.

Data processing and analysis: - The data were entered, cleaned and coded using EPI info version 3.5.1 and exported to SPSS version 16 statistical package for analysis. Frequencies and cross-tabulations were used to summarize the data. Bivariate and multivariate analyses were performed to test associations of information seeking behavior towards HIV/AIDS with the other covariates. A P-value of $\leq 0.05$ was considered as significantly associated with information seeking behavior.

Ethical consideration: - Ethical clearance was obtained from college review board.

\section{Results}

Socio-demographic Characteristics

A total of 705 construction workers were included in the study, with a response rate of $100 \%$. The mean age of the participant was $26.46 \pm 6.82$ (SD) years ranging from 19 to 63 years . Of the total, $55.7 \%$ were females and $87.5 \%$ were from urban areas. About two-third (71.6\%) of the study participants were unmarried, $96.7 \%$ were Orthodox Christian and $95.6 \%$ were Amhara by ethnicity. With regard to job category, nearly two-third (73.8\%) were unskilled construction workers and more than half (56.6\%) served for less than one year. 
Of 705 construction workers, 391(55.5\%) were under level-Il construction sites, of which 103(14.6\%) and from level-I construction site $97(13.8 \%)$ were categorized as having inappropriate information seeking behavior towards HIV/AIDS. Concerning advantages of information seeking behavior, 646(91.6\%) of workers reported that information seeking behavior has advantage to prevent HIV/AIDS, 632(89.6\%) reported that they have the role to know where the service is given and $553(78.4 \%)$ of workers mentioned that it has an advantage to get HIV/AIDS services.

Factors associated with information seeking behavior using multivariate logistic regression analysis

In the multivariate logistic regression analysis, comprehensive knowledge towards HIV, received HIV information from work place and being tested for HIV were positively associated with information seeking behavior towards HIV/AIDS, whereas workers sex (gender) is negatively associated with information seeking behavior (Table 1).

Workers who have comprehensive knowledge towards HIV/AIDS were 2.26 times more likely to have appropriate information seeking behavior towards HIV/AIDS than those do not have comprehensive knowledge towards HIV/AIDS [AOR = 2.26, 95\% Cl: 1.47-3.50]. Construction workers who received HIV information from work place were 1.52 times more likely to have appropriate information seeking behavior towards HIV/AIDS than workers who did not received HIV information from work place [AOR = 1.52, 95\% Cl:1.00-2.29]. Those Construction workers who tested for HIV were 1.81 times more likely to have appropriate information seeking behavior towards HIV/AIDS than workers who did not tested for HIV $[A O R=1.81,95 \% \mathrm{Cl}: 1.19-2.73]$. Female construction workers were $61 \%$ less likely to have appropriate information seeking behavior towards HIV/AIDS than male construction workers $[\mathrm{AOR}=0.39,95 \% \mathrm{Cl}$ : 0.27-0.56] (Table 1). 
Table 1

Bivariate and multivariate analysis of factors associated with information seeking behavior towards HIV/AIDS among construction workers in Debre Berhan town, Northeast Ethiopia, April 2019.

\begin{tabular}{|c|c|c|c|c|c|}
\hline \multirow[t]{2}{*}{ Variables } & & \multicolumn{2}{|c|}{$\begin{array}{l}\text { Information seeking } \\
\text { behavior }\end{array}$} & \multirow[t]{2}{*}{$\begin{array}{l}\text { COR } \\
(95 \% \mathrm{Cl})\end{array}$} & \multirow[t]{2}{*}{$\operatorname{AOR}(95 \% \mathrm{Cl})$} \\
\hline & & Appropriate & Inappropriate & & \\
\hline \multirow[t]{2}{*}{ Sex } & Male & $255(81.7 \%)$ & $57(18.3 \%)$ & 1.00 & \multirow{2}{*}{$\begin{array}{l}0.39(0.27- \\
0.56) \#\end{array}$} \\
\hline & Female & $250(63.6 \%)$ & $143(36.4 \%)$ & $\begin{array}{l}0.39(0.27- \\
0.56)\end{array}$ & \\
\hline \multirow[t]{2}{*}{ Marital status } & Married & 155(77.5\%) & $45(22.5 \%)$ & 1.00 & \\
\hline & Unmarried & $350(69.3 \%)$ & 155(30.7\%) & $\begin{array}{l}0.65(0.45- \\
0.96)\end{array}$ & \\
\hline \multirow[t]{4}{*}{$\begin{array}{l}\text { Educational } \\
\text { status }\end{array}$} & $\begin{array}{l}\text { Unable to } \\
\text { read/write }\end{array}$ & $70(63.6 \%)$ & $40(36.4 \%)$ & 1.00 & \\
\hline & Primary & 167(71.4\%) & $67(28.6 \%)$ & $\begin{array}{l}1.42(0.88- \\
2.30)\end{array}$ & \\
\hline & Secondary & 198(74.7\%) & $67(25.3 \%)$ & $\begin{array}{l}1.68(1.04- \\
2.72)\end{array}$ & \\
\hline & $\begin{array}{l}\text { College and } \\
\text { above }\end{array}$ & 70(72.9\%) & $26(27.1 \%)$ & $\begin{array}{l}1.53(0.84- \\
2.78)\end{array}$ & \\
\hline \multirow[t]{3}{*}{ Job category } & $\begin{array}{l}\text { Unskilled } \\
\text { worker }\end{array}$ & $362(69.9 \%)$ & $158(30.4 \%)$ & 1.00 & \\
\hline & $\begin{array}{l}\text { Skilled } \\
\text { worker }\end{array}$ & $112(78.9 \%)$ & $30(21.1 \%)$ & $\begin{array}{l}1.62(1.04- \\
2.54)\end{array}$ & \\
\hline & $\begin{array}{l}\text { Office } \\
\text { worker }\end{array}$ & $31(72.1 \%)$ & $12(27.9 \%)$ & $\begin{array}{l}1.12(0.56- \\
2.25)\end{array}$ & \\
\hline \multirow[t]{2}{*}{$\begin{array}{l}\text { Attitude towards } \\
\text { PLWHA }\end{array}$} & Positive & $311(74.9 \%)$ & $104(25.1 \%)$ & $\begin{array}{l}1.47(1.06- \\
2.05)\end{array}$ & \\
\hline & Negative & 194(66.9\%) & $96(33.1 \%)$ & 1.00 & \\
\hline \multirow[t]{2}{*}{$\begin{array}{l}\text { Know services about } \\
\text { ART }\end{array}$} & Yes & $464(73.5 \%)$ & $167(26.5 \%)$ & $\begin{array}{l}2.23(1.36- \\
3.65)\end{array}$ & \\
\hline & No & $53(31.0 \%)$ & $118(61.0 \%)$ & 1.00 & \\
\hline \multirow{2}{*}{$\begin{array}{l}\text { Comprehensive } \\
\text { Knowledge } \\
\text { about HIV }\end{array}$} & Yes & 167(83.5\%) & $33(16.5 \%)$ & $\begin{array}{l}2.50(1.64- \\
3.79)\end{array}$ & $\begin{array}{l}2.26(1.47- \\
3.50) \#\end{array}$ \\
\hline & No & $338(66.9 \%)$ & $167(33.1 \%)$ & 1.00 & 1.00 \\
\hline
\end{tabular}




\begin{tabular}{|c|c|c|c|c|c|}
\hline \multirow[t]{2}{*}{ Have radio } & Yes & $337(76.8 \%)$ & $102(23.2 \%)$ & \multicolumn{2}{|l|}{$\begin{array}{l}1.92(1.38- \\
2.69)\end{array}$} \\
\hline & No & $168(63.2 \%)$ & $98(36.8 \%)$ & 1.00 & \\
\hline \multirow[t]{2}{*}{ Have TV set } & Yes & 172(77.1\%) & $51(22.9 \%)$ & $\begin{array}{l}1.50(1.04- \\
2.17)\end{array}$ & \\
\hline & No & $333(69.1 \%)$ & $149(30.9 \%)$ & 1.00 & \\
\hline \multirow{2}{*}{$\begin{array}{l}\text { Received HIV } \\
\text { information from work } \\
\text { place }\end{array}$} & Yes & $147(78.2 \%)$ & $41(21.8 \%)$ & $\begin{array}{l}1.59(1.07- \\
2.36)\end{array}$ & $\begin{array}{l}1.52(1.00- \\
2.29)^{\star}\end{array}$ \\
\hline & No & $358(69.2 \%)$ & $159(30.8 \%)$ & 1.00 & 1.00 \\
\hline \multirow[t]{2}{*}{$\begin{array}{l}\text { Know place for HCT } \\
\text { Service }\end{array}$} & Yes & $466(73.3 \%)$ & $166(26.3 \%)$ & $\begin{array}{l}2.44(1.49- \\
4.00)\end{array}$ & \\
\hline & No & $39(53.4 \%)$ & $34(46.6 \%)$ & 1.00 & \\
\hline \multirow[t]{2}{*}{ Tested for HIV } & Yes & $416(75.2 \%)$ & $137(24.8 \%)$ & $\begin{array}{l}2.14(1.47- \\
3.13)\end{array}$ & $\begin{array}{l}1.81(1.19- \\
2.73)^{\star}\end{array}$ \\
\hline & No & $89(58.6 \%)$ & $63(41.4 \%)$ & 1.00 & 1.00 \\
\hline \multirow[t]{2}{*}{$\begin{array}{l}\text { Know services about } \\
\text { PMTCT }\end{array}$} & Yes & $427(73.2 \%)$ & $156(26.8 \%)$ & $\begin{array}{l}1.54(1.02- \\
2.33)\end{array}$ & \\
\hline & No & 78(63.9\%) & $44(36.1 \%)$ & 1.00 & \\
\hline
\end{tabular}

\section{Discussion}

This study has yielded important information about information seeking behavior towards HIV/AIDS and associated factors among construction workers. Information seeking behavior towards HIV/AIDS is a key in the prevention and control of HIV/AIDS for this vulnerable and most economically important group.

This study showed that $28.4 \%$ of construction workers had inappropriate information seeking behavior towards HIV/AIDS. According to a study done in northwest Ethiopia, information need on HIV in urban and rural were $50.6 \% 11.2 \%$ respectively (21). This showed that the level of appropriate information seeking behavior towards HIV/AIDS among construction workers is not satisfactory according to the domain expert explanation. The reason for this could be low comprehensive knowledge towards HIV/AIDS among the group (6).

Female construction workers were $61 \%$ less likely to have appropriate information seeking behavior towards HIV/AIDS than male workers. Nearly all quantitative studies reported more women were searching for health information on the internet than men(28). The possible reason for this discrepancy could be that there is a difference in study area, period and study participants. 
Of all construction workers, almost all (99.1\%) reported that they heard about HIV/AIDS. This result is similar with EDHS data 2011, majority of the respondents, $97 \%$ of women and $99 \%$ of men, (6), Sir Lanka (81.6\%) (24), and Nigeria (99.7\%) (23) had heard of HIV/AIDS.

Even though majority of respondents had heard of HIV/AIDS, this study revealed that comprehensive knowledge of AIDS is low, only $28.4 \%$ of construction workers have comprehensive knowledge on HIV/AIDS. This finding is in line with EDHS 2011, only 19\% women and 32\% men have comprehensive knowledge about HIV/AIDS (6).This may be a reason not to have appropriate information seeking behavior towards HIV/AIDS.

In this study the main source of information about HIV/AIDS were mass media, especially radio, television and health providers, $80.3 \%, 54.3 \%$ and $49.5 \%$ respectively. This result is similar with the study conducted in South Africa, most respondents obtained their information from radio and television programs $96.3 \%$ and $95.4 \%$ respectively(20), Nigeria (94.7\%) from television(23).

Regarding HIV information received at work place, this study showed that $26.7 \%$ workers who had received HIV information at work place. This could be mainly because of lack of construction sectors mainstreaming HIV/AIDS prevention and control activities in their work plan. This result differs from a study conducted in South Africa that $61 \%$ of respondents reported that they had obtained any HIV/AIDS information at workplace(20). This might be due to low attention to work place HIV prevention and control implementation strategy in the construction sector in the country.

With regard to HIV testing, this study showed that $78.4 \%$ of workers have ever been tested for HIV. Knowledge of HIV status helps HIV negative individuals make specific decisions to reduce risk and increase safer sex practices so that they can remain free of disease. EDHS 2011 reported that $36 \%$ of women and $38 \%$ of men had ever been tested for HIV and received their test results(6).

\section{Conclusion}

Appropriate information seeking behavior towards HIV/AIDS among construction workers was not satisfactory. Comprehensive knowledge of HIV/AIDS, workers sex, and HIV information received from work place and HIV testing were predictors for the presence of appropriate information seeking behavior towards HIV/AIDS.

\section{Abbreviations}

HIV: Human Immunodeficiency Virus ,AIDS: Acquired Immune Deficiency Syndrome, WHO: World Health organization

\section{Declarations}

Acknowledgements 
I sincerely express my gratitude to the Debre Berhan Health science college, for their support to conduct this research project. We would also like to thank the Department of Public Health, Debre berhan University,for facilitating the timely completion of this research project.

Availability of data and materials

The data collected for this study can be obtained from the author upon a reasonable request.

Authors' contributions

Authors developed the study, proposal writing, designed the study, responsible for data collection, analyzed the data, drafted the first version of manuscript, and participated in all phases of the project.

Ethics approval and consent to participate

Ethical clearance was obtained from the Institution Review Board of the college of Debre Berhan Health science. Permission was obtained from the woreda health office and health department included in the study. Brief explanation has been given to all respondents about the purpose of the study, and the privacy of their responses during data collection was maintained. Verbal consent was received from each respondent before the data collection. It was clearly stated that their response was only for research purpose, and the data collected were kept confidential.

Consent for publication

Not applicable.

Competing interests

The authors declare that they have no competing interests.

Author details

1. Department of Public Health, Institute of Medicine and Health Sciences, College of Health science,Debre Berhan University, P.O. Box 445, Debre Berhan, Ethiopia.

\section{References}

1.Wilson TD. Human Information Behavior. University of Sheffield, UK. 2000; 3(2).

2.University of Sheffield, UK. Wilson TD. On user studies and information needs [internet]. Journal of Librarianship. 1981;37(1):3-15.

3.Mohamed A. Information needs and information seeking behavior of Libyan doctors working in Libyan hospitals [A Doctoral Thesis]. Libya: Loughborough University; 2011. 
4.HIV/AIDS Information Seeking and Healthcare Communications in Sub-Saharan Africa,Durban, South Africa August 2007.

5.UNAIDS. Report on the global AIDS epidemic. 2012:8.

6.Central Statistical Agency of Ethiopia and ICF International. Ethiopia Demographic and Health Survey 2011,March 2012.

7.WHO,UNAIDS,UNICEF.Global HIV/AIDS Response:Epidemic Update and Health Sector Progress towards Universal Access. Geneva,Switzerland 2011.

8.Joint United Nations Programme on HIV/AIDS. Global Report: UNAIDS Report on the Global AIDS Epidemic: 2010. Geneva,Switzerland 2010.

9.Federal HIV/AIDS Prevention and Control Office. Country Progress Report on HIV/AIDS Response, April 2012.

10.ILO. An ILO code of practice on HIV/AIDS and the world of work. Geneva: International Labour Organization. 2001: 52.

11.HIV/AIDS, International Development, sustainability, Published August 9th, 2012.

12.WilsonTD. Models in information behaviour research. Journal of Documentation.1999;55(3):249-270.

13.Marchionini GM. Information-Seeking in Electronic Environments.Cambridge, Eng. Cambridge University Press.1995.

14.Case DO.Looking for information.a survey of research on information seeking, needs, and behavior.Amsterdam Boston :Elsevier/Academic, 2007, $2^{\text {nd }}$ ed.

15.Garner W.Uncertainty and structure as psychological concepts, Wiley, New York.1962.

16.Johnson J.Cancer-related information seeking, Hampton Press, Cresskill, N.J.1997.

17.Leckie $\mathrm{G}$ et al. Modeling the informationseeking of professionals. A general model derived from research on engineers, health care professionals, and lawyers.Library Quarterly, 1996,66(2):161-193.

18.Nicolaisen. $\mathrm{J}$ "Compromised need and the label effect. An examination of claims and evidence". Journal of the American Society for Information Science and Technology. 2004-2009,60 (10).

19.Kedir N. Knowledge, Attitude and Practices related to HIV/AIDS among most at risk populations at large scale construction sites in Ethiopia. November 2009.

20.Theo $\mathrm{C}$ et al. Combating HIV and AIDS in South African Construction through Effective Communication.2004,30-31. 
21.Mesfin A. and Steven E.HIV/AIDS-related information needs of urban and rural residents of northwest Ethiopia.January 2019.

22.Myint T et al. Knowledge, Attitude and Practices on HIV/AIDS Prevention among Myanmar Migrants in Maha Chai, Samut Sakhon Province:132.

23.Durojaiye OC. Knowledge, attitude and practice of HIV/AIDS: Behavior change among tertiary education students in Lagos, Nigeria. Ann Trop Med Public Health 2011;4:18-24.

24.Kanda $k$ et al.KAP on HIV/AIDS among construction workers in Sri Lanka. 2009;3(8):611-619.

25.The Construction Industry Development Board of South Africa: Specification for HIV/AIDS Awareness, June 2003.

26.Bureau of Addis Ababa Trade and Industry Development, 2006.

27.Goswami, D., \& Melkote, S. (1997). Knowledge gap in AIDS communication: An Indian case study. International Communication Gazette, 59, 205-221.

28.Christine M. and Chun W. review of theoretical models of health information seeking on the web,September 2011. 